\title{
Idiopathic non-histaminergic acquired angioedema: a case series and discussion of published clinical trials
}

\author{
Martin Christian Bucher ${ }^{1}$, Tatjana Petkovic ${ }^{2}$, Arthur Helbling ${ }^{3}$ and Urs Christian Steiner ${ }^{\text {** }}$
}

\begin{abstract}
Background: Idiopathic non-histaminergic acquired angioedema (InH-AAE) is a rare disease for which there are no available laboratory parameters to clearly define the disorder. Therapy is often difficult and various treatment options have been proposed. In this paper, we have evaluated the most effective therapies for InH-AAE on the basis of current literature and report the therapeutic effect of omalizumab in three patients with InH-AAE.
\end{abstract}

Methods: Literature was searched with a combination of MeSH/EMTREE terms and freetext search for angioedema and therapy/omalizumab in the databases Medline (Ovid), PubMed/Premedline, Embase, Cochrane library and Scopus with no time or language restrictions. In three patients affected by InH-AAE the therapeutic effect of omalizumab was demonstrated by clinical outcome. In one patient the FcERI receptor density on basophils was monitored under therapy with omalizumab.

Results: From the review of the current literature, 25 out of 286 publications dealing with relevant therapeutic recommendations for InH-AAE were analyzed. Six publications with 98 patients referred to tranexamic acid, of which 27 had a complete, 70 a partial and 1 no response. In three case reports ecallantide showed 2 patients with a complete and 1 a partial response. In four case reports for Icatibant 2 had a complete and 3 a partial response. When evaluated in three reports, $\mathrm{C} 1-\mathrm{INH}$ found complete and partial responses in 2 patients each. One patient had a complete response to progestin. Omalizumab was described in 6 reports with 20 patients, all of whom showed a complete response. All three patients described in our study responded to omalizumab with a complete remission. Density of Fc\&Rl receptors on basophils, monitored in patient 1 on a long-term course of 31 months, decreased from 74,051.61 to a minimal level of 1907 receptors per cell.

Conclusions: Omalizumab seems to be the most effective therapy in InH-AAE. The continuous decrease of FceRIreceptor density on basophils under therapy with omalizumab along with clinical improvement observed in one patient, could serve as a new approach for further studies to evaluate FcERI-receptor density as a surrogate marker for therapeutic efficacy and for dosing and determining injection intervals of omalizumab.

Trial registration BASEC-Nr. Req-2016-00692. Retrospectively registered 24.11.2016.

Keywords: Idiopathic angioedema, Mast cell, FceRl-receptor density, Omalizumab

\section{Background}

Angioedema (AE) is defined as a localized swelling of the subcutaneous and/or submucosal tissue caused by an increase of vascular permeability, which is induced by

\footnotetext{
${ }^{*}$ Correspondence: urs.steiner@usz.ch

1 Department of Clinical Immunology, University Hospital Zurich,

Gloriastrasse 23, 8091 Zurich, Switzerland

Full list of author information is available at the end of the article
}

vasoactive mediators [1]. Although most often associated with urticaria, angioedema represents its own entity $[2$, 3]. According to a recent consensus report, angioedemas without urticaria are classified in three hereditary (HAE), and four acquired (AAE) forms [4] (Table 1).

Idiopathic AAE are the most frequently occurring forms of angioedemas [3-5]. Diagnostic laboratory parameters are not yet available for diagnosing and 
Table 1 Forms of Angioedemas without wheals

Hereditary angioedemas
HAE with C1-inhibitor deficiency (C1-INH_HAE)
HAE with FXII mutations (FXII-HAE)
HAE of unknown origin (U-HAE)
Acquired angioedemas
Idiopathic histaminergic acquired angioedema (IH-AAE)
Idiopathic non-histaminergic acuired angioedema (InH-AAE)
Acquired angioedema related to angiotensin-converting enzyme inhibi-
tor (ACEi-AAE)
Aquired angioedema with C1-inhibitor deficiency (C1-INH-AAE)

Modified from Cicardi et al. [4]

differentiating the two idiopathic acquired forms, Idiopathic histaminergic acquired angioedema (IH-AAE) and Idiopathic non-histaminergic acquired angioedema (InH-AAE) [6]. Diagnosis of IH-AAE is considered if the angioedema responds to antihistamines. The lack of response to antihistamines defines InHAAE $[4,7]$.

Therapy of InH-AAE is often challenging. This is reflected by a wide variety of therapeutic options for InH-AAE, such as high dosages of antihistamines (AH), icatibant, ecallantide, C1-INH concentrates, glucocorticosteroids (GCS), omalizumab, and other agents.

In this study we give an overview of the different and most effective therapeutic modalities for InH-AAE according the current literature. We further report the clinical response of omalizumab in three patients affected by InH-AAE. In one patient we monitored the FceRIreceptor density of basophils during therapy over a period of 31 months.

\section{Methods}

The local Ethical Review Board of Zurich assessed the design of this observational and retrospective study and offered a waiver (Req-2016-00692). The study strictly adhered to the principles of good clinical practice and the ethical standards outlined in the Declaration of Helsinki [8]. All patients were verbally informed and gave their written informed consent for this study.

\section{Patients}

All three patients suffering from angioedemas for years were referred to the out-patient clinic of allergy and clinical immunology. After a detailed allergological and immunological work up, they were diagnosed as $\mathrm{InH}$ AAE. Complement factor $\mathrm{C} 4$ level, $\mathrm{C} 1$ inhibitor level and $\mathrm{C} 1$ inhibitor function were within the normal range. None of them underwent treatment with ACE inhibitors, sartans, gliptins or NSAID.

\section{Comprehensive review of the literature}

Literature was searched with a combination of $\mathrm{MeSH} /$ EMTREE terms and freetext search for angioedema and therapy/omalizumab in the databases Medline (Ovid), PubMed/Premedline, Embase, Cochrane library and Scopus with no time or language restrictions. The detailed search protocol is shown in Additional file 1.

\section{FcERI receptor density measurement}

Peripheral blood mononuclear cells (PBMCs) were isolated from anticoagulant-treated venous blood by density gradient centrifugation using Ficoll Paque (Amersham Pharmacia Biosciences, Uppsala, Sweden). The surface density of FceRI on donor basophils was determined by means of DAKO QIFIKIT $^{\circledR}$ (Dako-Cytomation, City, Denmark): Freshly isolated PBMCs were resuspended in CellWASH ${ }^{\circledR}$ (BD Bioscience, San Jose, CA, USA) and stained with primary mouse monoclonal anti-FceRI antibodies (eBioscience, San Diego, CA, USA). Subsequently, goat anti-mouse fluorescein isothiocyanate (FITC) conjugated immunoglobulin $\left.\mathrm{F}(\mathrm{ab})_{2}\right)_{2}$ fragments were added to detect bound anti-FceRI (Dako Denmark, 2008, QIFIKIT $^{\circledR}$ Code K0078). Finally, to identify basophils, staining with anti-CCR3-PE (BioLegend, San Diego, CA, USA) was performed. The antibody-binding capacity of basophils was determined by the mean fluorescent intensity measured by the FACSCanto ${ }^{\circledR}$ (BD Bioscience, San Jose, CA, USA) flow cytometer using a calibration curve set up with beads of known antibody concentration from the DAKO QIFIKIT ${ }^{\circledR}$.

\section{Results}

\section{Comprehensive review of the literature}

From the 499 retrieved publications 213 were duplicates. Of the remaining 286 publications, 25 trials, consisting of case reports, case series and retrospective observational studies with relevant therapeutic recommendations for InH-AAE, were selected and analyzed.

Six case reports or retrospective trials describe the efficacy of tranexamic acid (TA) in InH-AAE. Out of 98 patients, 27 responded completely, 70 partially, and 1 patient showed no response [3, 9-13].

Three case reports showed a complete response in 2 and a partial response in 1 patient treated with ecallantide [14-16]. Therapy with icatibant is described in four case reports. A complete response was shown in 2, and a partial response in 3 patients [14, 17-19].

In three case reports with C1-INH 2 patients had a complete and 2 patients a partial response $[14,19,20]$.

In a retrospective study of 50 patients, progestin decreased the frequency of angioedema attacks in 45 women. Twenty of them were affected by idiopathic $\mathrm{AE}$ and $80 \%$ responded with a partial response [21]. 
In six reports 20 patients with InH-AAE were treated with omalizumab. All had a complete response [22-27].

Five Individual reports with 1 patient each were described for ciclosporin with no response [28], dapsone [29], fresh frozen plasma [30], rituximab [31] and cannabis [32] - all of them with a complete response (Table 2).

\section{Case reports}

Patient 1

A 67-year-old white female with a 3-year history of recurrent, twice-weekly angioedemas of the lips, tongue and larynx. The clinical response of the angioedemas to the intake of antihistamines $(\mathrm{AH})$ of doses up to three times higher than that normally recommended was not sufficient. Thus, glococorticosteroids (GCS) on a weekly basis were often necessary to control the symptoms. Omalizumab $150 \mathrm{mg}$ was administered subcutaneously in 4-week intervals. After the first injection of omalizumab, facial swellings improved markedly. Treatment with $\mathrm{AH}$ and GCS were discontinued after 8 weeks. Omalizumab was paused after the fourth injection. Eleven weeks after stopping therapy, facial angioedemas reoccurred (Fig. 1).

Table 2 Comparison of the therapies most often applied in InH-AAE

\begin{tabular}{|c|c|c|c|c|}
\hline & Reference & $\begin{array}{l}\text { Number } \\
\text { of patients }\end{array}$ & Drug/doses & $\begin{array}{l}\text { Response: } \mathrm{cr} / \mathrm{pr} / \mathrm{nr} \\
\text { (number of patients) }\end{array}$ \\
\hline \multicolumn{5}{|c|}{ Medical influence of coagulation and contact activation pathway } \\
\hline \multirow[t]{6}{*}{ Tranexamic acid } & [9] & 2 & 1-4 g per day & $\operatorname{cr} 2$ \\
\hline & [10] & 1 & NA & cr 1 \\
\hline & [11] & 15 & 0.5-3 g per day & $\operatorname{cr} 8 / p r 7$ \\
\hline & [12] & 23 & $0.5-3$ g per day & cr 12/pr 11 \\
\hline & [13] & 19 & 1-3 g per day & cr 4/pr 15 \\
\hline & [3] & 38 & $0.5-3$ g per day & pr 37/nr 1 \\
\hline \multirow[t]{3}{*}{ Ecallantide } & [15] & 1 & 30 mg (during attacks) & cr 1 \\
\hline & [16] & 1 & 30 mg (during attacks) & $\operatorname{cr} 1$ \\
\hline & [14] & 1 & NA & pr 1 \\
\hline \multirow[t]{4}{*}{ Icatibant } & [17] & 1 & 30 mg (during attacks) & $\mathrm{cr} 1$ \\
\hline & [18] & 1 & 30 mg (during attacks) & $\mathrm{cr} 1$ \\
\hline & [14] & 1 & NA & pr 1 \\
\hline & [19] & 2 & 30 mg (during attack) & pr 2 \\
\hline \multirow[t]{3}{*}{ C1-INH } & [14] & 1 & 1000U twice weekly & $\mathrm{cr} 1$ \\
\hline & [19] & 2 & NA & pr 2 \\
\hline & {$[20]$} & 1 & $1000 U$ twice weekly & $\mathrm{cr} 1$ \\
\hline \multicolumn{5}{|c|}{ Medical influence of the hormonal axis } \\
\hline Progestin & {$[21]$} & 20 & Various dosages depending the progestin & cr $6 /$ pr $10 /$ nr 4 \\
\hline \multicolumn{5}{|c|}{ Medical influence of IgE antibodies and mast cell (Omalizumab) } \\
\hline \multirow[t]{6}{*}{ Omalizumab } & {$[46]$} & 3 & 300 mg every 3-4 weeks; 375 mg every 2 weeks & $\mathrm{Cr} 3$ \\
\hline & [23] & 1 & $\begin{array}{l}300 \mathrm{mg} \text { every } 4 \text { weeks initially, then reduced to } \\
300 \mathrm{mg} \text { every } 8 \text { weeks }\end{array}$ & $\mathrm{cr} 1$ \\
\hline & [24] & 1 & 300 mg every 4 weeks & $\mathrm{cr} 1$ \\
\hline & [25] & 8 & $\begin{array}{l}300 \mathrm{mg} \text { every } 4 \text { weeks initially, then reduced to doses } \\
\text { and intervals according to symptoms }\end{array}$ & $\operatorname{cr} 8$ \\
\hline & [27] & 2 & $\begin{array}{l}375 \mathrm{mg} \text { every } 2 \text { weeks initially, then reduced to } \\
375 \mathrm{mg} \text { every } 4 \text { weeks }\end{array}$ & $\operatorname{cr} 2$ \\
\hline & {$[26]$} & 5 & 300 mg every $2-4$ weeks & $\operatorname{cr} 5$ \\
\hline \multicolumn{5}{|c|}{ Other immunosuppressants or immunomodulatory therapies } \\
\hline Dapsone & {$[29]$} & 1 & 50 mg per day & $\mathrm{cr} 1$ \\
\hline Ciclosporin & [28] & 1 & 300 mg per day & nr 1 \\
\hline FFP & [30] & 1 & 4 units & $\mathrm{cr} 1$ \\
\hline Rituximab & [31] & 1 & $\begin{array}{l}560 \mathrm{mg}\left(375 \mathrm{mg} / \mathrm{m}^{2} \text { body surface area) weekly for }\right. \\
4 \text { weeks }\end{array}$ & $\mathrm{cr} 1$ \\
\hline Cannabis & [32] & 1 & 20 g per month, inhaled $2-3 \times$ per week & $\mathrm{cr} 1$ \\
\hline
\end{tabular}

cr complete remission, $p r$ partial remission, $n r$ no response, NA not available, FFP fresh frozen plasma 


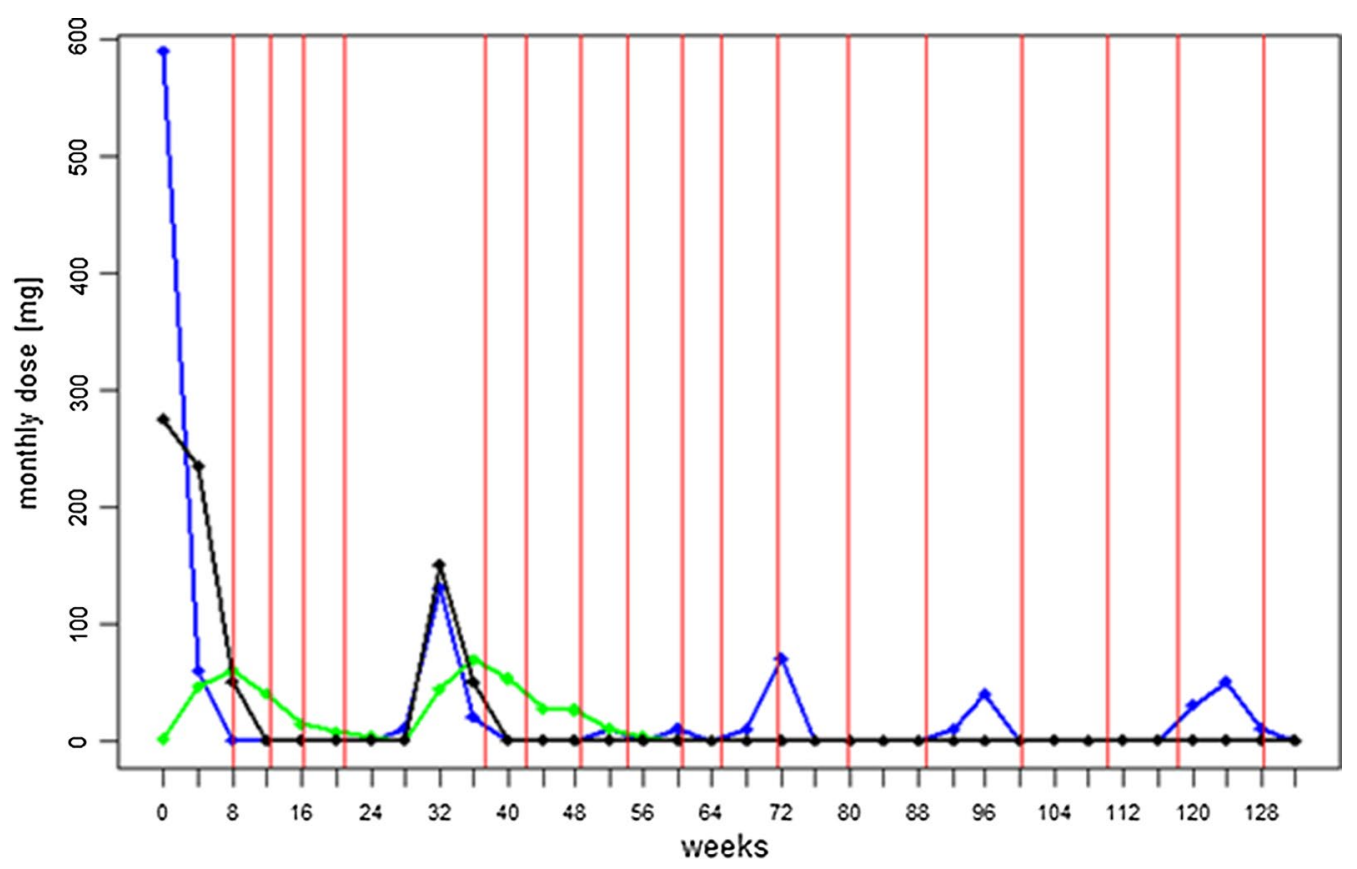

Fig. 1 Medication use during treatment with omalizumab in patient 1. Red solid line Omalizumab injections; black solid line Prednisone intake; blue solid line Cetirizine intake; green solid line Ketotifen intake. Average doses of AH and oral glucocorticoids were calculated for every month in the past two and a half years

Omalizumab $150 \mathrm{mg}$ was resumed and the angioedema disappeared after 1 week. The patient stayed symptomfree. The interval between injections was stretched to every 2 months and the patient stayed symptom-free with only intermittent discrete eyelid swellings.

\section{Patient 2}

A 46-year-old white male suffering for 9 years from weekly recurrent non-itchy angioedemas on the feet, face and tongue. Due to laryngeal angioedema with airwayocclusion, emergency treatment was necessary in 2013. Suggested triggers were mechanical stress, cold, infections, and NSAIDs. Following a job change with associated mental pressure, angioedemas were not controllable with high doses of AH. Treatment with omalizumab was started, using $300 \mathrm{mg}$ s.c. at monthly intervals. Concomitant $\mathrm{AH}$ intake was reduced and finally completely discontinued after 2 weeks. After 1 year of treatment, the dose was reduced to $150 \mathrm{mg}$ and has been given every month since, without recurrence of symptoms.

\section{Patient 3}

A 27-year-old white female suffering for 8 months from weekly recurrent angioedema of the lips and periorbital region without pruritus. No trigger factors were noticed. Since swelling episodes were not controllable with $\mathrm{AH}$ and GCS, doses of $300 \mathrm{mg}$ s.c. of omalizumab were initiated at intervals of every 4 weeks. After the second injection no further angioedema episodes occurred.

\section{FcERI-receptor density in patient 1}

Density of FceRI receptor on basophils was monitored in patient 1 (ADR-AC GmbH, Bern, Switzerland). Density decreased remarkably from $74,051.61$ to $10,892.93 \mathrm{rpc}$ after the second injection of omalizumab $150 \mathrm{mg}$. After the 4th injection, after which omalizumab was discontinued, FceRI-receptor density increased up to $21,666.53 \mathrm{rpc}$ during the 16-week pause. After reintroduction of omalizumab $150 \mathrm{mg}$ at intervals of 4 to 8 weeks over 31 months, the FceRI-receptor density decreased to a minimal level of 1,907rpc (see Fig. 2).

\section{Discussion}

In 2014 an international working group proposed a classification of angioedemas without wheals [4]. However, characterisation and differentiation of InH-AAE remain difficult and evidence of treatment efficacy is limited to case reports and uncontrolled small case series. Based on the literature, a wide range of different therapies are used for InH-AAE. TA is the most frequently used therapy for Inh-AAE. It inhibits plasminogen activation and therefore limits FXIIa activation and C1-INH consumption by plasmin. This leads to a decrease of bradykinin formation [33, 34]. In the trials described, about one 


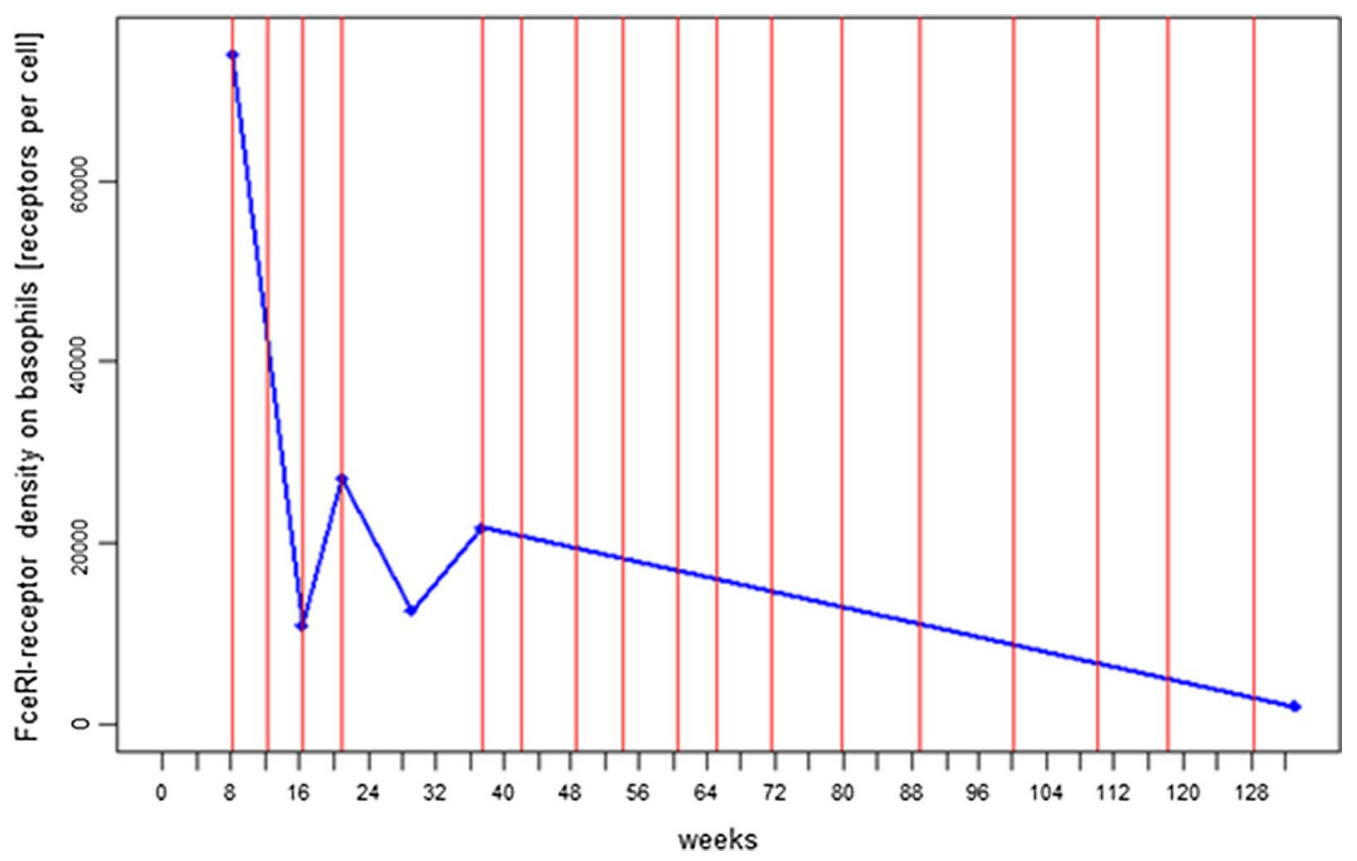

Fig. 2 Long-term therapy treatment of density of FceRI-receptors on basophils in patient 1. Red solid line Omalizumab injections; blue solid line FcદRI-receptor density. Receptor density decreased substantially during treatment with omalizumab over 31 months from 74,051 receptors per cell before start of treatment, to 1,907 receptors per cell

third of the 98 patients had a complete response to TA as prophylaxis for InH-AAE [3, 9-13]. Both ecallantide, a kallikrein receptor antagonist, and $\mathrm{C} 1-\mathrm{INH}$, a serine protease with inhibitory activities in the complement system and the contact-,coagulation-, and fibrinolytic pathways, reduce the generation of Bradykinin. Ecallantide was effective in all described patients with Inh-AAE for acute attacks. C1-INH was effective for acute attacks and was also valuable for long term prophylaxis [14-16, 19, 20]. Icatibant, a competitive bradykinin B2 receptor antagonist, selectively prevents the effect of bradykinin on the endothelium. Used in acute attacks, it showed a good but short-lived response in most of the patients. Progestin modulates endogenous oestrogen and therefore reduces activation of FXII and the contact activation pathway which leads to a control of angioedema in HAE patients with C1-Inh deficiency [35, 36]. Saule et al. [21] reported favourable experience with progestins to prevent attacks in any type of non-allergic angioedema. Omalizumab, a humanized IgG monoclonal antibody directed against $\mathrm{IgE}$ antibodies reduces free IgE levels which results in the downregulation of FceRI receptors on basophils and mast cells [37, 38]. Given the current state of knowledge, these effects prevent IgG autoantibodies from cross-linking FcERI receptors, cell activation is suppressed, the threshold of mast cell degranulation is increased, and possible autoreactive IgE antibodies can not longer bind the high affinity receptor $[39,40]$. In the described case reports and case series all patients diagnosed with Inh-AAE responded to omalizumab.

With regard to the mode of action of the different medications against InH AAE, the drug either interacts with IgE antibodies and influences the mast cells, as does omalizumab, or it interacts with the coagulation and contact activation pathway, as do tranexamic acid (TA), icatibant, ecallantide, $\mathrm{C} 1-\mathrm{INH}$ and progestin (compare Table 2). This indicates that mast cells and the contact activation pathway are linked by mediators most probably secreted by mast cells. As recently discovered, heparin from activated mast cells induces the contact activation pathway by FXII [41]. These findings beg the conclusion that activated mast cells not only induce histamine induced angioedemas by secreting their mediators.

About $40-50 \%$ of patients with chronic spontaneous urticaria (CSU) have episodes of angioedema and a part of them show the symptoms of angioedema without wheals. IH-AAE shares a lot of similarities with CSU. Many patients with CSU remain symptomatic in spite of antihistamine therapy up to four times the approved dose $[42,43]$. In these patients ciclosporin and omalizumab are recommended as an addon therapy. When IH-AAE is associated with CSU responding to antihistamines, Inh-AAE should be associated with CSU patients not responding to antihistamines. 
All three patients described in this report had full remission after the second injection of omalizumab and remained free of symptoms when omalizumab was given continuously. This is in line with the described case reports and series so far, where all patients treated with omalizumab had a complete response. In patient 1 we were able to document the decrease of receptor density in correlation with clinical response (Figs. 1, 2). The follow-up of FceRI-receptor density on basophils over 31 months showed an impressive continuous decrease of receptor density when omalizumab was regularly administered and it allowed us to adapt the therapy individually.

\section{Strength and limitations}

In this study a comprehensive overview of the literature of the different treatments in Inh-AAE could be provided. However, a deficiency lies in the fact that the effect of medications interacting with the contact activation pathway in the same patients who responded to omalizumab was not examined. Another downside of the study is that the long term course of FceRI-receptor density was demonstrated in one patient only.

\section{Conclusion}

InH-AAE shares similarities to patients with CSU which do not respond to antihistamines. Omalizumab is the most promising therapeutic approach for prophylaxis in Inh-AAE. Not only is histamine involved in the formation of angioedemas, but also other mediators of activated mast cells which interact with the contact pathway.

As the clinical course corresponds with FceRI-receptor density [39], this receptor could be evaluated as a biomarker to monitor the therapeutic effect and adjust the dose of omalizumab for long term therapy.

Better knowledge about how and why mast cells are activated and release their mediators more or less selectively, will enable us to design new and more personalized therapies $[44,45]$.

\section{Additional file}

Additional file 1. The detailed search protocol for Medline.

\section{Abbreviations \\ AE: angioedema; C1-INH-HAE: hereditary angioedema with C1 inhibitor deficiency; IH-AAE: idiopathic histaminergic acquired angioedema; InH-AAE: idiopathic non-histaminergic acquired angioedema; AH: antihistamines; GCS glucocorticosteroids; PBMCs: peripheral blood mononuclear cells; rpc: recep- tor per cell.}

\section{Authors' contribution}

MB: analyzed the patients' histories; accumulation, analysis and interpretation of data; revised the manuscript; TP: conducted the FcERI receptor density measurement; revised the manuscript; US: carried out the concept and design of the study; accumulation, analysis and interpretation of data, revised the manuscript; AH: analyzed the patients' histories; revised the manuscript. All authors read and approved the final manuscript.

\section{Author details}

${ }^{1}$ Department of Clinical Immunology, University Hospital Zurich, Gloriastrasse 23, 8091 Zurich, Switzerland. ${ }^{2}$ Adverse Drug Reaction-Analysis and Consulting (ADR-AC) GmbH, Bern, Switzerland. ${ }^{3}$ Department of Rheumatology, Immunology and Allergology, Inselspital, University Bern, Bern, Switzerland.

\section{Acknowledgements}

The authors would like to thank Dr. Martina Gosteli, main library, University of Zurich, for the literature search.

\section{Competing interests}

The authors declare that they have no competing interests.

\section{Availability of data and materials}

All data generated or analysed during this study are included in this published article.

\section{Ethics approval and consent to participate}

The local Ethical Review Board of Zurich offered a waiver for this study (Req-2016-00692). All patients were verbally informed and gave their written informed consent for this study.

\section{Publisher's Note}

Springer Nature remains neutral with regard to jurisdictional claims in published maps and institutional affiliations.

Received: 23 December 2016 Accepted: 17 July 2017

Published online: 31 August 2017

\section{References}

1. Kaplan AP, Greaves MW. Angioedema. J Am Acad Dermatol. 2005;53:37388 (quiz 389-392)

2. Aberer W. Angioedema is not just 'deep urticaria' but an entity of its own. Allergy. 2014;69:549-52.

3. Mansi M, Zanichelli A, Coerezza A, Suffritti C, Wu MA, Vacchini R, Stieber C, Cichon S, Cicardi M. Presentation, diagnosis and treatment of angioedema without wheals: a retrospective analysis of a cohort of 1058 patients. J Intern Med. 2015;277:585-93.

4. Cicardi M, Aberer W, Banerji A, Bas M, Bernstein JA, Bork K, Caballero T, Farkas H, Grumach A, Kaplan AP, et al. Classification, diagnosis, and approach to treatment for angioedema: consensus report from the Hereditary Angioedema International Working Group. Allergy. 2014;69:602-16.

5. Zingale LC, Beltrami L, Zanichelli A, Maggioni L, Pappalardo E, Cicardi B, Cicardi M. Angioedema without urticaria: a large clinical survey. CMAJ. 2006;175:1065-70.

6. Farkas H, Veszeli N, Kajdácsi E, Cervenak L, Varga L. "Nuts and bolts" of laboratory evaluation of angioedema. Clin Rev Allergy Immunol. 2016;51:140-51.

7. Faisant C, Boccon-Gibod I, Mansard C, Dumestre Perard C, Pralong P, Chatain C, Deroux A, Bouillet L. Idiopathic histaminergic angioedema without wheals: a case series of 31 patients. Clin Exp Immunol. 2016;185:81-5.

8. World Medical Association. Declaration of Helsinki ethical principles for medical research involving human subjects. J Am Coll Dent. 2014:81:14-8.

9. Thompson RA, Felix-Davies DD. Response of 'idiopathic' recurrent angioneurotic oedema to tranexamic acid. BMJ. 1978;2:608.

10. Hakansson OM. Menstruation-related angioedema treated with tranexamic acid. Acta Obstet Gynecol Scand. 1988;67:571-2.

11. Cicardi $M$, Bergamaschini L, Zingale LC, Gioffre D, Agostoni A. Idiopathic nonhistaminergic angioedema. Am J Med. 1999;106:650-4.

12. Du-Thanh A, Raison-Peyron N, Drouet C, Guillot B. Efficacy of tranexamic acid in sporadic idiopathic bradykinin angioedema. Allergy. 2010;65:793-5. 
13. Wintenberger C, Boccon-Gibod I, Launay D, Fain O, Kanny G, Jeandel PY, Martin L, Gompel A, Bouillet L. Tranexamic acid as maintenance treatment for non-histaminergic angioedema: analysis of efficacy and safety in 37 patients. Clin Exp Immunol. 2014;178:112-7.

14. Stahl MC, Harris CK, Matto S, Bernstein JA. Idiopathic nonhistaminergic angioedema successfully treated with ecallantide, icatibant, and $\mathrm{C} 1$ esterase inhibitor replacement. J Allergy Clin Immunol Pract. 2014;2:818-9.

15. Berry A, Firszt R. Successful treatment of idiopathic angioedema with ecallantide. J Allergy Clin Immunol Pract. 2013;1:297-8.

16. Dy TB, Rasheed M, Parikh P, Bernstein L. Resolution of an acute attack of idiopathic angioedema with ecallantide. Ann Allergy Asthma Immunol. 2013;111:224-6.

17. Del Corso I, Puxeddu I, Sardano E, Geraci S, Breggia M, Rocchi V, Migliorini P. Treatment of idiopathic nonhistaminergic angioedema with bradykinin B2 receptor antagonist icatibant. Ann Allergy Asthma Immunol. 2012;108:460-1.

18. Montinaro V, Loizzo G, Zito A, Castellano G, Gesualdo L. Successful treatment of a facial attack of angioedema with icatibant in a patient with idiopathic angioedema. Am J Emerg Med. 2013;31:1295.e1295-6.

19. Shroba J, Hanson J, Portnoy J. Current treatment options for idiopathic angioedema. Ann Allergy Asthma Immunol. 2015;115:429-33.

20. Gravante C, Carucci L, Bova M, Petraroli A, Genovese A, Marone G. Prophylactic treatment with plasma-derived $\mathrm{C} 1$ inhibitor in idiopathic non-histaminergic angioedema. Pediatr Allergy Immunol. 2016;27:658-9.

21. Saule C, Boccon-Gibod I, Fain O, Kanny G, Plu-Bureau G, Martin L, Launay $D$, Bouillet $L$, Gompel A. Benefits of progestin contraception in nonallergic angioedema. Clin Exp Allergy. 2013;43:475-82.

22. Sands MF, Blume JW, Schwartz SA. Successful treatment of 3 patients with recurrent idiopathic angioedema with omalizumab. J Allergy Clin Immunol. 2007;120:979-81.

23. von Websky A, Reich K, Steinkraus V, Breuer K. Complete remission of severe chronic recurrent angioedema of unknown cause with omalizumab. J Dtsch Dermatol Ges. 2013;11:677-8.

24. Ozturk $A B$, Kocaturk E. Omalizumab in recurring larynx angioedema: a case report. Asia Pac Allergy. 2014;4:129-30.

25. Azofra J, Díaz C, Antépara I, Jaúregui I, Soriano A, Ferrer M. Positive response to omalizumab in patients with acquired idiopathic nonhistaminergic angioedema. Ann Allergy Asthma Immunol. 2015;114:418e411-419e411.

26. Faisant C, Du Thanh A, Mansard C, Deroux A, Boccon-Gibod I, Bouillet L. Idiopathic non-histaminergic angioedema: successful treatment with omalizumab in five patients. J Clin Immunol. 2016:37:80-4.

27. Munoz JP, Casado AF, Taboada AC, Campos Munoz L, Bran EL. Successful treatment of refractory idiopathic angio-oedema with omalizumab: review of the literature and function of IgE in angio-oedema. Clin Exp Dermatol. 2016:41:399-402.

28. Şener O, Bolu E, Akyol S. Cyclosporine A in the treatment of chronic idiopathic angioedema: a case report. Gulhane Med J. 2005:47:228-30.

29. Gonzalez P, Soriano V, Caballero T, Niveiro E. Idiopatic angioedema treated with dapsone. Allergol Immunopathol. 2005;33:54-6.

30. Franzen D, Ursprung T, Wuthrich B, Reber A. Idiopathic non-histaminergic angio-oedema after routine extubation successfully treated with fresh frozen plasma. Anaesthesia. 2006:61:698-701.
31. Ghazan-Shahi S, Ellis AK. Severe steroid-dependent idiopathic angioedema with response to rituximab. Ann Allergy Asthma Immunol. 2011;107:374-6.

32. Frenkel A, Roy-Shapira A, Evgeni B, Leonid K, Borer A, Klein M. Life threatening idiopathic recurrent angioedema responding to cannabis. Case Rep Immunol. 2015;2015:780824.

33. Tengborn L, Blomback M, Berntorp E. Tranexamic acid —an old drug still going strong and making a revival. Thromb Res. 2015;135:231-42.

34. Kaplan AP, Joseph K. Complement, Kinins, and hereditary angioedema: mechanisms of Plasma Instability when C1 Inhibitor is Absent. Clin Rev Allergy Immunol. 2016;51:207-15.

35. Citarella F, Misiti S, Felici A, Farsetti A, Pontecorvi A, Fantoni A. Estrogen induction and contact phase activation of human factor XII. Steroids. 1996;61:270-6

36. Bork K, Fischer B, Dewald G. Recurrent episodes of skin angioedema and severe attacks of abdominal pain induced by oral contraceptives or hormone replacement therapy. Am J Med. 2003;114:294-8,

37. MacGlashan DW Jr, Bochner BS, Adelman DC, Jardieu PM, Togias A, McKenzie-White J, Sterbinsky SA, Hamilton RG, Lichtenstein LM. Downregulation of Fc(epsilon)Rl expression on human basophils during in vivo treatment of atopic patients with anti-lgE antibody. J Immunol. 1997:158:1438-45.

38. Beck LA, Marcotte GV, MacGlashan D, Togias A, Saini S. Omalizumabinduced reductions in mast cell Fce psilon Rl expression and function. J Allergy Clin Immunol. 2004;114:527-30.

39. Metz M, Staubach P, Bauer A, Brehler R, Gericke J, Kangas M, AshtonChess J, Jarvis P, Georgiou P, Canvin J, et al. Clinical efficacy of omalizumab in chronic spontaneous urticaria is associated with a reduction of FcepsilonRI-positive cells in the skin. Theranostics. 2017:7:1266-76.

40. Kaplan AP, Gimenez-Arnau AM, Saini SS. Mechanisms of action that contribute to efficacy of omalizumab in chronic spontaneous urticaria. Allergy. 2017;72:519-33.

41. Oschatz C, Maas C, Lecher B, Jansen T, Bjorkqvist J, Tradler T, Sedlmeier R, Burfeind $\mathrm{P}$, Cichon $\mathrm{S}$, Hammerschmidt $\mathrm{S}$, et al. Mast cells increase vascular permeability by heparin-initiated bradykinin formation in vivo. Immunity. 2011;34:258-68.

42. Maurer M, Weller K, Bindslev-Jensen C, Gimenez-Arnau A, Bousquet PJ, Bousquet J, Canonica GW, Church MK, Godse KV, Grattan CE, et al. Unmet clinical needs in chronic spontaneous urticaria. A GA(2)LEN task force report. Allergy. 2011;66:317-30.

43. Guillen-Aguinaga S, Jauregui Presa I, Aguinaga-Ontoso E, Guillen-Grima F, Ferrer M. Updosing nonsedating antihistamines in patients with chronic spontaneous urticaria: a systematic review and meta-analysis. Br J Dermatol. 2016:175:1153-65.

44. Theoharides TC, Kempuraj D, Tagen M, Conti P, Kalogeromitros D. Differential release of mast cell mediators and the pathogenesis of inflammation. Immunol Rev. 2007;217:65-78.

45. Harvima IT, Levi-Schaffer F, Draber P, Friedman S, Polakovicova I, Gibbs BF, Blank U, Nilsson G, Maurer M. Molecular targets on mast cells and basophils for novel therapies. J Allergy Clin Immunol. 2014;134:530-44.

\section{Submit your next manuscript to BioMed Central and we will help you at every step:}

- We accept pre-submission inquiries

- Our selector tool helps you to find the most relevant journal

- We provide round the clock customer support

- Convenient online submission

- Thorough peer review

- Inclusion in PubMed and all major indexing services

- Maximum visibility for your research

Submit your manuscript at www.biomedcentral.com/submit
(OioMed Central 